\title{
PENGARUH PENGHARGAAN (REWARD) DAN MOTIVASI BERPRESTASI TERHADAP PRESTASI KERJA GURU SMA NEGERI DI KABUPATEN SUKABUMI
}

\author{
Siti Nurpina*
}

\begin{abstract}
This study aims to determine the effect of (1) rewrad, (2) achievement motivation, (3) performance of teachers working SMAN Negeri District of SukabumI. In the data analysis, this study used a survey method using a causal analysis technique Strip. This study used a sample of 150 teachers in six high schools in District of Sukabumi are selected using Slovin formula. The results showed that : first, there are positive influence between the rewrad and performance of teachers in schools. Secondly, there is a positive effect between achievement motivation and performance of teachers in schools. Third, there is a positive effect between the reward and achievement motivatioan of teachers in schools.
\end{abstract}

Key words: reward, achievement motivation, performance

\section{PENDAHULUAN}

Pendidikan mempunyai peran yang sangat penting dalam perkembangan dan kelangsungan hidup bangsa. Personil yang berhubungan langsung dengan tugas penyelenggaraan pendidikan adalah kepala sekolah dan guru. Dalam pelaksanaan fungsi dan tugasnya, guru sebagai profesi yang menyandang persyaratan tertentu dan keberhasilan pendidikan itu tentu guru sebagai ujung tombak untuk mencetak pendidikan yang berkualitas.

Kualitas pendidikan di Indonesia diharapkan merata dari Sabang sampai Marauke, dari pulai Nias sampai pulau Rote. Pemerintah berupaya semaksimal mungkin meningkatkan kualitas pendidikan di Indonesia. Berbagai usaha dilakukan pemerintah agar segenap lapisan masyarakat menikmati pendidikan yang berkualitas. Salah satu upaya pemerintah meningkatkan kualitas pendidikan adalah dengan adanya perubahan kurikulum secara berkala setiap sepuluh tahun, bahkan selalu mengadakan penelitian dan evaluasi terhadap perubahan kurikulum.

Setiap lapisan masyarakat berharap dan mendambakan pendidikan yang berkualitas, sehingga anak-anak mereka mendapatkan pendidikan yang berkualitas. Dengan pendidikan yang berkualitas diharapkan mereka dapat menjadi generasi yang siap pakai, dapat bersaing dengan tenaga asing. Dengan demikian generasi muda dapat berkontribusi dalam membangun bangsa ini dan dapat melanjutkan tongkat perjuangan para pendahulunya.

Kualitas pendidikan mempunyai makna sebagai proses dan hasil yang menyeluruh. Proses yang dimaksud adalah segala aktivitas pelaksanaan pendidikan dalam berbagai dimensi, baik yang dijalankan oleh guru sebagai tenaga pendidikan, pemerintah sebagai pemangku kebijakan dan kegiatan yang dilakukan anak didik sebagai obyek sekaligus subyek pendidikan. Hasil pendidikan merupakan hasil dari proses yang dilakukan semua elemen yang berkontribusi dalam pendidikan.

Untuk memperoleh hasil pendidikan yang berkualitas tidak lepas peran para guru sebagai pelaku pendidikan. Guru merupakan penentu keberhasilan pendidikan di

\footnotetext{
*Wirausaha
} 
sekolah melalui prestasi kerjanya. Tugas pokok guru adalah mendidik, mengajar, membimbing dan melatih. Guru dapat menjalankan tugas pokoknya dengan baik apabila didukung dengan adanya sebuah apresiasi penghargaan (reward) yang diberikan oleh pihak sekolah untuk meningkatkan motivasi guru sehingga prestasi dan kualitas pendidikan sekolah tersebut meningkat.

Hasil informasi informasi yang didapat dari Kepala Seksi (Kasi) kurikulum dan kesiswaan SMA/SMK Dinas Pendidikan (Disdik) Kabupaten Sukabumi, menjelaskan bahwa ada beberapa faktor yang memperlambat meningkatnya prestasi guru, diantaranya kurangnya keterampilan mengajar dikelas, sudah jelas bahwa banyak sekali keterampilan yang harus dimiliki oleh guru, dan untuk menguasai keterampilanketerampian tersebut guru membutuhkan bimbingan dan pembinaan insentif yang dapat meningkatkan keterampilan dalam mengajar. Disamping itu, prestasi guru dalam melaksanakan tugas perlu ditunjang oleh faktor internal yang muncul dari dalam diri atau faktor eksternal berasal dari luar individu guru, seperti sikap profesional, disiplin kerja serta motivasi kerja untuk berprestasi sangat diperlukan untuk dapat meningkatkan prestasi kerja guru. Kesungguhan melaksankan tugas timbul berkat kesadaran atas tugas yang menjadi tanggung jawab, motivasi untuk bekerja, serta sikapnya terhadap profesi. Faktor lain yang berasal dari luar individu yang dapat menjadi faktor penentu prestasi kerja guru antara lain pembinaan atau supervisi yang dilakukan kepala sekolah, kepemimpinan kepala sekolah, kurangnya sebuah apresiasi yang diberikan oleh sekolah/hadiah/penghargaan, lingkungan kerja dan iklim organisasi sangat diperlukan untuk mendorong meningkatnya prestasi kerja guru.

\section{Prestasi Kerja}

Anderson (2001:8), mengemukan bahwa "the term 'performance' is used to refer to the proficiency with which individuals carry out behaviors or activites that are relevant to the organization." Istilah prestasi kerja digunakan untuk merujuk kepada kemampuan individu dalam melakukan pekerjaan yang relevan untuk organisasi. Masih dalam buku yang sama dikatakan, 'the term 'performance' is sometimes used to refer to the profiency with which groups or organizational carry out specific types of activities. According to this definition, performance reflects the proficiency with which the group applies knowledge, skill, and professionalism to the task." Istilah prestasi kerja terkadang digunakan untuk melihat kemampuan individu dalam kelompok atau organisasi untuk melaksanakan berbagai jenis pekerjaan. Menurut definisi ini, prestasi kerja mencerminkan kemampuan menjalankan tugas dalam kelompok untuk menerapkan pengetahuan, keterampilan, dan usaha secara profesionalisme dalam menjalankan tugas. Kevin R. Muphy (1999:143), "it seems reasonable to assume that the definition of job performance should not include all behaviors that accour on the job, but rather only some subset of relevant behaviors that are clearly linked to accomplishing the specific tasks that are included in a person's job." Prestasi kerja tidak harus mencakup semua prilaku yang terjadi pada pekerjaan, tetapi hanya beberapa bagian dari prilaku yang relevan. Salah satu cara untuk mendefinisikan perilaku yang relevan tersebut yaitu perilaku yang jelas terkait dalam menyelesaikan tugas-tugas khusus yang termasuk dalam pekerjaan seseorang. Menurut Sabine Sonnentang (2000:156), "performance as behaviour or action that is relevant for the achievement of organization's goals and that can be scaled (measured) in terms of level of proficiency (or contribution to goals) that is representd by a particular action or set of actions." Prestasi kerja adalah perilaku atau usaha yang relevan untuk mencapai tujuan organisasi yang dapat dinyatakan dalam skala (terukur) dalam tingkat keahlian (atau kontribusinya pada 
tujuan) yang ditunjukan dalam tingkatan tertentu atau serangkaian tindakan. Selanjutnya Mullins (2006:45), "a major influencing factor affecting work performance is the ability of the employee. Ensuring that the right people are selected for work and are able to use their intelligence effectively is a critical personnel process responsible for the job." Mullins menjelaskan bahwa Faktor utama yang mempengaruhi prestasi kerja adalah kemampuan karyawan. Memastikan bahwa orang yang tepat yang dipilih untuk bekerja dan mampu menggunakan kecerdasan mereka secara efektif dalam proses personil pegawai dan bertanggung jawab atas tugas masing-masing.

Berdasarkan konsep-konsep yang telah diuraikan diatas dapat disintetiskan prestasi kerja adalah tampilan sorang pegawai dalam serangkaian proses pelaksanaan tugas dan pekerjaan yang dicapai oleh seorang pegawai dan keterampilan yang ditunjukkan di dalam melakukan pekerjaan secara professional selama kurun waktu tertentu, dengan indikator: (1) profesionalisme dalam menjalankan tugas, (2) pelaksanaan dan pencapaian tujuan organisasi, (3) tanggung jawab terhadap tugas.

\section{Penghargaan (Reward)}

Griffin dan Moorhead (2009:151), berpendapat bahwa "an individual's compensation package is the total array of money (wages, salari, commission), incetives, benefits, perguisites, and award provided by the organization". Paket kompensasi bagi individu meliputi sejumlah uang (upah, gaji, komisi/ pemberian bonus), insentif, tunjangan, dan penghargaan lainya seperti pengkuan dan pemberian pujian yang diberikan oleh organisasi terhadap pegawai. Selanjutnya Amstrong (2007:31) menyatakan bahwa, "framework rewards can be: 1) intrinsic rewards are usually non-financial reward in the form of Desai work and development of the role (responsibility, autonomy, work meaning, scope to use and develop skills), the opportunity to excel and grow, the quality of working life, promotion opportunities, and the balance of work; 2) extrinsic rewards in the form of financial reward (wages and profits) and non-financial peghargaan form of awards (rekoknisi), praise and feedback." Adapun kerangka penghargaan dapat berupa: 1) penghargaan instrinsik biasanya penghargaan non-finansial berupa desai kerja dan pengembangan peran (tanggung jawab, otonomi, kerja berarti, cakupan untuk menggunakan dan mengembangkan keahlian), kesempatan untuk berprestasi dan berkembang, kualitas kehidupan kerja, kesempatan promosi, dan keseimbangan kerja; 2) penghargaan ekstrinsik berupa penghargaan finansial (upah dan keuntungan) dan peghargaan non-finansial berupa penghargaan (rekoknisi), pujian dan umpan balik. Kemudian Neil Anderson (1998:173) menjelakan bahwa penghargaan sebagai berikut, "reward is contingent on effort expended performance level achieved and self-development opportunities." Dalam hal ini Penghargaan (Reward) bergantung pada usaha yang dikeluarkan dan tingkat kinerja yang dicapai sehingga dapat mengembangkan kesempatan untung pengembangan diri.

Berdasarkan uraian di atas, maka dapat disintesiskan penghargaan (reward) adalah segala bentuk balas jasa yang diberikan kepada seseorang atas hasil pekerjaanyang dilakukan ditandai dengan: (1) kesempatan pengembangan diri (2) pemberian bonus (3) pengakuan dan pemberian pujian dan (4) kesempatan promosi. 


\section{Motivasi Berprestasi}

Menurut Stephen P. Robbins dan Mary Coulter (2012:452), menjelelaskan bahwa "motivation is the process by which a person's efforts are energized, directed, and sustained toward attaining a goal". Motivasi adalah proses dimana upaya seseorang diberi energy untuk bekerja keras, diarahkan, dan berkelanjutan untuk menuju pencapaian tujuan. Menurut Jennifer M. George dan Gareth R. Jones (2012:182) motivasi berprestasi memiliki tiga elemen, "direction of behavior, level of effort, and level if persistence." Arah perilaku, tingkat usaha dan kegigihan. Arah perilaku berkenaan dengan perilaku mana yang dipilih untuk dilakukan dari banyak perilaku potensial yang dapat dilakukan. Tingkat usaha berarti seberapa keras seseorang bekerja untuk melakukan sebuah perilaku yang telah dipilih. Menurut Jeremy Stranks (2005:92-93), dijelaskan mengenai motivasi bahwa "the term 'motive' implies a need and the direction of behaviour towards a goal, aim or objective. A 'motivator', on the other hand, is something that provides the drive to produce certain behaviour or to mould behaviour. 'Motivation' is a term used to describe the goals or objectives that a person endeavours to meet and the drive or motivating force that keeps him on track in pursuing these goals or objectives." Istilah 'motif' menyiratkan kebutuhan dan arah perilaku untuk mencapai tujuan. motivasi di sisi lain, adalah sesuatu yang memberikan dorongan untuk menghasilkan perilaku tertentu atau untuk membentuk perilaku. 'Motivasi' adalah istilah yang digunakan untuk menggambarkan tujuan atau sasaran bahwa orang berusaha untuk memenuhi atau memotivasi kekuatan yang membuat dia semangat dalam mengejar tujuan dengan kemauan maksimal, untuk menyelesaikan tugas sesuai standard maksimal. Selanjutnya menurut John R. Schermerhorn (2010:310), "achievement motivation should be most effective for challenging tasks that require initiative and the assumption of personal responsibility for success." Motivasi berprestasi harus lebih efektif untuk tugas-tugas yang menantang yang membutuhkan inisiatif dan asumsi tanggung jawab pribadi dan kemandirian untuk bertindak untuk mencapai kesuksesan.

Berdasarkan deskripsi teori yang dikemukakan di atas dapat disintesiskan motivasi berprestasi adalah dorongan atau keinginan untuk mencapai hasil kerja terbaik yang ditunjukkan oleh perilaku dalam (1) bekerja keras, (2) kegigihan untuk memperoleh hasil kerja maksimal, (3) kemampuan maksimal untuk bekerja, (4) kemandirian untuk bertindak, (5) kemauan mencapai lebih standard kerja, (6) kemauan untuk menyelesaikan tugas sesuai standard maksimal.

\section{METODE}

Penelitian ini bertujuan untuk menguji pengaruh langsung; (1) penghargaan (reward) terhadap prestasi kerja, (2) motivasi berprestasi terhadap prestasi kerja, dan (3) penghargaan terhadap motivasi berprestasi. Penelitian menggunakan metode survey dengan pendekatan teknik analisis jalur. Penelitian dilaksanakan di SMA Negeri Kabupaten Sukabumi. Populasi terjangkau penelitian ini sejumlah 241 guru. Sampel penelitian sebayak 150 orang. Analisa data untuk pengujian hipotesis akan dilakukan dengan menggunakan teknik analisis jalur, yaitu teknik yang diterapkan untuk menjelaskan pengaruh antara variabel-variabel penelitian. Sebelum dilaksanakan analisis jalur, uji signifikan regresi dan uji linearitas regresi sebagai prasyarat uji statistik dilakukan pengujian penormalan data dari masing-masing variabel penelitian dengan Uji-Liliefors, Statistik inferensial digunakan untuk menguji hipotesis tentang pengaruh antar variabel dengan menggunakan tehnik analisis jalur. 


\section{HASIL DAN PEMBAHASAN}

\section{Pengaruh Penghargaan (Reward) terhadap Prestasi Kerja}

Dari hasil pengujian hipotesis pertama dapat disimpulkan bahwa terdapat pengaruh langsung positif pengargaan (reward) terhadap prestasi kerja dengan nilai koefisien korelasi sebesar 3,19 dan nilai koefisien jalur sebesar 0,232. Ini memberikan makna penghargaan (reward) berpengaruh langsung terhadap prestasi kerja.

Hasil penelitian ini senada dengan pendapat beberapa ahli di antaranya adalah Hye Jung Yoon (2015:19), menjelaskan bahwa "the effect of rewards on creative performance was moderated by the degree of importance of that reward as perceived by the employee." Pengaruh penghargaan terhadap prestasi kerja yang kreatif dimoderatori oleh tingkat pentingnya penghargaan seperti yang dirasakan oleh karyawan. Carton (2012:301), menjelaskan, "previous reward studies often focused on the effects of tangible rewards on task performance, with monetary gain most commonly used." Penghargaan berfokus pada efek atau pengaruh yang nyata pada Prestasi kerja, dengan keuntungan yang paling umum digunakan. Michael Amstrong (2006:11), mengatakan bahwa "performance management can play an important part in a total reward system in which each reward element is linked together an effect as an integrated and coherent whole. These elements comprise base pay, contingent pay, employee benefits, and non-financial rewards, which include intrinsic reward from the work itself. it is sometimes assumed that the main purpose of performance management is to generate ratings to inform contribution or performance related pay decisions. Performance management can provide for a whole range of rewards in order to encourage job engagement and promote commitment. These reward can take the form of recognition through feedback, opportunities to achieve the scope to develop skills, and guidance on career paths." Dijelaskan bahwa Manajemen prestasi dapat memainkan peranan penting dalam sistem penghargaan (reward) keseluruhan di mana setiap elemen penghargaan (reward) mempengaruhi bersama-sama sebuah terkait sebagai suatu keseluruhan yang terpadu dan koheren. Unsur-unsur ini terdiri gaji pokok, gaji kontingen, imbalan kerja, dan imbalan non-finansial, yang meliputi imbalan intrinsik dari pekerjaan itu sendiri. kadang-kadang diasumsikan bahwa tujuan utama dari manajemen prestasi adalah untuk menghasilkan penilaian untuk menginformasikan kontribusi atau keputusan membayar kinerja terkait. Manajemen prestasi dapat menyediakan berbagai macam penghargaan (reward) untuk mendorong keterlibatan kerja dan mempromosikan komitmen. Penghargaan (Reward) ini dapat mengambil bentuk pengakuan melalui umpan balik, peluang untuk mencapai lingkup untuk mengembangkan keterampilan, dan bimbingan pada jalur karir.

\section{Pengaruh Motivasi Berprestasi terhadap Prestasi kerja}

Dari hasil pengujian hipotesis kedua dapat disimpulkan bahwa terdapat pengaruh langsung positif motivasi berprestasi terhadap prestasi kerja dengan nilai koefisien korelasi sebesar 3,22 dan nilai koefisien jalur sebesar 0,237. Ini memberikan makna motivasi berprestasi berpengaruh langsung terhadap prestasi kerja.

Robert N. Lussier (2010:42), mengemukakan bahwa "achievement motivation theory attemps to explain and predict behaviour and performance based on a person's need for achievement, power, and affiliation". Motivasi berprestasi mencoba menjelaskan dan 
memprediksi perilaku dan prestasi kerja berdasarkan pada kebutuhan seorang akan prestasi, kekuasaan dan keanggotaan. Jadi motivasi berprestasi erat kaitannya dengan kebutuhan seseorang akan prestasi dirinya. Selanjutnya, Benjamin Schnider dan D. Brent Smith (2004:257), mengatakan bahwa "motives energize and direct behavior into global behavioral patterns, that is, general achievement, power, and affiliation behavioral patterns." Motivasi energi dan perilaku langsung ke dalam pola perilaku yang umum, diantaranya prestasi, kekuatan, dan pola perilaku afiliasi. Jadi secara langsung motivasi mempengaruhi pola perilaku untuk berprestasi. Selain itu menurut Jerald Greenberg (2010:176), mengemukakan bahwa "just a people are motivated to satisfy their needs on the job, to be paid fairly, and to act in ways consistent with their beliefs about reality, they also are motivated to strive for and to attain goals. The process of setting goals is one of the most term goal setting refers to the process of setting goals in a manner that motivates workers to raise their performance." Hanya orang termotivasi untuk memenuhi kebutuhan mereka pada pekerjaan, yang harus dibayar cukup, dan bertindak dengan cara yang konsisten dengan keyakinan mereka tentang realitas, mereka juga termotivasi berjuang untuk mencapai tujuan. Proses penetapan tujuan adalah salah satu yang paling tetap dan tujuan ini merujuk pada proses menetapkan tujuan dengan cara yang memotivasi pekerja untuk meningkatkan prestasi kerja mereka.

\section{Pengaruh Penghargaan (Reward) terhadap Motivasi berprestasi}

Dari hasil pengujian hipotesis ketiga dapat disimpulkan bahwa terdapat pengaruh langsung positif penghargaan terhadap motivasi berprestasi dengan nilai koefisien korelasi sebesar 3,67 dan nilai koefisien jalur sebesar 0,367. Ini memberikan makna penghargaan berpengaruh langsung terhadap motivasi berprestasi.

Fred Luthans dan Jonathan (2012:446), menyatakan bahwa "managers everywhere use rewards to motivate their personnel. Sometimes these are financial in nature such as salary raises, bonuses, and stock, and stock options. At other times there are non-financial such as feedback and recognition." Dalam pandangan ini Manajer/pimpinan di mana-mana menggunakan penghargaan (reward) untuk memotivasi pegawai mereka. Kadangkadang ini bisa dalam bentuk keuangan seperti kenaikan gaji, bonus, saham, dan opsi saham. Di lain waktu ada non-keuangan seperti umpan balik dan pengakuan. Selanjutnya Fred Luthans (2001:90), mengemukakan bahwa "organization provide rewards to their personnel in order to try to motivate their performance and encourage their loyalty and retention." Organisasi memberikan penghargaan (reward) kepada pegawai mereka dalam rangka untuk mencoba memotivasi prestasi mereka dan mendorong loyalitas dan retensi mereka, jadi penghargaan mempengaruhi motivasi berprestasi dan mendorong loyalitas dan retensi mereka sehingga kebanyakan organisasi menggunakan penghargaan (reward) untuk memotivasi pegawai. Stephen R. Balzac (2011;76) menjelaskan bahwa, "If you really want rewards to motivate, find out what individual employees would like. While money is easy to give and rarely turned down, taking the time to find something appropriate for an employee is often not only less expensive for the company bit far more motivating. The fact that you took the time to figure out what someone would really like magnifies the effect of the reward several-fold. Jika Anda benar-benar ingin hadiah untuk memotivasi, cari tahu apa yang pegawai inginkan. Sementara uang mudah untuk memberikan dan jarang ditolak, meluangkan waktu untuk menemukan sesuatu yang sesuai untuk pegawai ini akan membuat karyawan untuk termotivasi berprestasi. Dan mngambil waktu untuk mencari tahu apa yang orang benar-benar ingin pegawai inginkan, maka memperbesar keinginan untuk mendapatkan pengharaan (rewrard). 


\section{PENUTUP}

Kesimpulan: Berdasarkan hasil penelitian yang dilakukan terhadap guru SMA Negeri di Kabupaten Sukabumi, diperoleh kesimpulan penelitian sebagai berikut : 1) Penghargaan (reward) berpengaruh langsung positif terhadap prestasi kerja. Artinya, ketepatan dalam pemberian penghargaan yang dirasakan guru menyebabkan peningkatan prestasi kerja guru SMA Negeri di Kabupaten Sukabumi. 2) Motivasi berprestasi berpengaruh langsung positif terhadap prestasi kerja. Artinya, peningkatan motivasi berprestasi mengakibatkan peningkatan prestasi kerja guru SMA Negeri di Kabupaten Sukabumi. 3) Penghargaan (reward) berpengaruh langsung positif terhadap motivasi berprestasi. Artinya, ketepatan dalam pemberian penghargaan yang dirasakan guru mengakibatkan peningkatan motivasi berprestasi guru SMA Negeri di Kabupaten Sukabumi.

Saran: Berdasarkan penelitian yang telah dilakukan, dapat disampaikan saran-saran yang dapat meningkatkan prestasi kerja gurudiantaranya sebagai berikut: 1) Bagi Kepala Sekolah memiliki peran penting dalam meningkatkan prestasi kerja guru. Beberapa hal yang sebaiknya dilakukan oleh Kepala Sekolah adalah : a) Kepala sekolah memberikan kesempatan kepada guru untuk mengikuti pelatihan-pelatihan yang mendukung pekerjaanya. b) Kepala sekolah tepat dalam memberikan penghargaan terhadap guru yang berprestasi. c) Kepala sekolah mengikutsertakan guru untuk diklat pelaksanaan secara berkala biasanya setiap tahun sekali pada awal tahun atau ketika ada program diklat diikutkan. d) Kepala sekolah terbuka baik antar guru maupun guru dengan kepala sekolah. e) Kepala Sekolah menunjukkan kepada tenaga pendidik \& tenaga kependidikan tentang bagaimana cara untuk sukses. f) Kepala Sekolah selalu memberikan pujian terhadap guru yang berprestasi. g) Kepala Sekolah dapat memotivasi guru dapat dilakukan dengan meningkatkan harapan guru dari hasil kerjanya yakni dengan meningkatkan penghasilannya, meningkatkan kesejahteraanya, pemberian penghargaan, mempermudah kenaikan pangkat/jabatan dan bantuan hukum apabila terkena kasus hukum. 2) Bagi Dinas Pendidikan mengadakan pelatihan yang terkait dengan peningkatan kompetensi guru. 3) Bagi Guru: a) Guru perlu berpartisipasi aktif untuk memberikan ide, gagasan, kreativitas untuk meningkatkan prestasi kerja sekolah. b) Guru rajin dalam mengikuti pelatihan yang terkit dengan kompetensi guru. c) Guru saling memotivasi antar guru untuk menjadi guru yang berprestasi dalm upaya meningkatkan prestasi guru itu sendiri maupun prestasi sekolah. 


\section{DAFTAR RUJUKAN}

Anderson, L.W., dan Karthwal, D.R. (2001). A Taxsonomy For Learning, Teaching, and Assesing. A Revision of Blooms Taxsonomy of Education Objectives. New York; Wesley Lonman Inc.

Benjamin Schnider dan D. Brent Smith. (2004). Personality and Organization. New Jersey: LEA.

Carton. (2012). The differential effects of tangible rewards and praise on intrinsic motivation: A comparison of cognitive evaluation theory and operant theory. International Journal of Methods in Psychiatric Research. Vol. 21 (4), h. 301.

Fred Luthans. (2001). Organizational Behavior: An Evidence Based Approach. New York: McGraw-Hill.

Fred luthans and jonathan P. (2012). International Management: culture, strategy and Behavior. New York: McGraw-Hill.

Hye Jung Yoon., et al. (2015). Mechanisms Underlying Creative Performance: Employee Perceptions Of Instrinsic and Extrinsic Rewards For Creativity. International Journal: Social Behavior \& Personality. Vol. 43 (7), h. 19.

Jerald Greenberg. (2010). Managing Behavior in Organizations. New Jersey: Prentice Hall.

Jeremy Stranks. (2005). Stress at Work: Management and Prevention. India: Elsevier.

John R. Schermerhorn., et al. (2010). Organizational Behavior. USA: Wiley \& Sons, Inc.

Kevin R Muphy., et al. (1999). Understanding Performance Appraisal. California: Sage.

Michael Amstrong. (2007). handbook of employee reward managemen and practice. London: Kogan Page.

Michael Amstrong. (2006). Performance Management: Key Strategies and Partical Guidelines. London: British Library Cataloguing.

Mullins, Laurie J. (2006). Essentials of Organisational Behavior. London: Prentice Hall.

Neil Anderson., et al. (2001). Handbook of Indusrial, Work and Organizational Psychology. London: Sage Publications.

Neil Anderson., et al. (1998). organizational Perspectivies, New Jersey: Prentice Hall.

Ricky W. Griffin dan Georgy Moorhead. (2009). Organizational Behavior: Managing people and Organizational. Mason: Cengage Learning.

Robert L. Mathis, John H. Jakson. (2010). Human Resource Management. United States: McGraw-hill International. 
Sabine Sonnentag. (2000). Psychological Manajement of Individual Performance. New York: John Willey and Son.

Stephen P. Robbins Mary Coulter. (2012). Management. New York: Prentice Hall.

Stephen R. Balzac. (2011). Organizational Development. USA: McGraw-Hill 